ORIGINAL ARTICLE

LEAL, Cícero Pereira ${ }^{[1]}$

LEAL, Cícero Pereira. Doing and Thinking: How the Legislator thinks - practices and ideologies. Revista Científica Multidisciplinar Núcleo do Conhecimento. Year 05, Ed. 12, Vol. 18, pp. 116-130. December 2020. ISSN: 2448-0959, Access Link: https://www.nucleodoconhecimento.com.br/social-sciences/practices-and-ideologies, DOI: 10.32749/nucleodoconhecimento.com.br/social-sciences/practices-and-ideologies

Contents

- SUMMARY

- INTRODUCTION

- METHODOLOGICAL PATHS OF RESEARCH

- THEORETICAL FRAMEWORK

- CONSIDERATIONS

- BIBLIOGRAPHY

- APPENDIX - FOOTNOTE REFERENCES

\title{
SUMMARY
}

The study aims to identify in the literature some characteristics that compose and influence the decisions of public policies. We can infer that ideologies: personal, social and party influence in the votes of parliament's representatives. To this end, we conducted a bibliographic survey where we found some characteristics, which does not exclude others that can be contemplated in other studies. Thus, it was observed that personal, social and political issues can generate changes in the behavior - directly or indirectly - of the representatives elected by society, leading to changes in the voting process, now meeting agendas: personal, social and/or partisan. The work was divided into an introduction of the seminal literature where it deals with representatives pre-selected by all, but not responding to anyone. In the second part, we present the paths taken for the development of work. The theoretical literature is shown in the third part and the considerations we leave in the fourth 
part of the text.

Key words: Ideology, parliamentary profile, polarization, exchanges.

INTRODUCTION

The French philosopher Jean-Jacques Rousseau was one of the first heavyweights of hegemonic political culture. He intended to develop a political model that would ensure democracy, as private property promotes inequality and endangers freedom. A political model that established a state, upheld private property, and determined public property as something of everyone without belonging to any person. In this way, political representation would be at the service of all, however, being of all, it would not belong to anyone. According to Rousseau, political representation would start from the "will of all" of society to the "general will", that is, the representatives pre-selected by all, but not responding to anyone. According to Carl Schmitt, representing means making an absentee present, that is, no one (BENJAMIN, 2008).

Rousseau's concepts were inserted into the Constitution of the United States and the consequent constitutions of the French Revolution. The French Revolution generated a historical change of the modern world system, presenting two fundamental changes, which organized the basis of the political culture of the modern world system: the normality of political change and the reformulation of the concept of sovereignty, with a focus on the citizen-people. The understanding of popular sovereignty, if it was inclusive, resulted in the exclusion of a large majority of people. In the 19th and 20th centuries, presented a debate between the included and excluded, this discussion took place in a geoculture that expressed the inclusion of all as synonymous with a just society (PINTO; GUIMARÃES; BARROS, 2016).

According to Ceron (2015), the parties act as actors, thus being the members exhibit the behavior according to their legend. However, this statement does not reflect reality. The parties are not structures of political monopoly, as they are usually composed of a variety of subgroups (i.e. factions) maintaining similar but not identical preferences. Aware of such internal heterogeneity, scholars have investigated the elements that impact the level of party unity to assess the conditions under which members of the same group behave consistently 
or (better) choose different options.

Studies on party unity present several answers to this phenomenon (heterogeneity). In addition to some comparative studies evaluating the impact of different political systems (Carey, 2007, 2009; Depauw and Martin, 2009; Kam, 2009; Sieberer, 2006), cited by Ceron (2015), where a series of articles analyze party unity in a single country. These works shed light on the elements that affect the willingness to party divisions. They draw attention to the heterogeneity of political preferences, the degree of partisanship, the impact of contrasting electoral rules or modes of party organization, the differences between government and opposition, the margin of the ruling coalition and the size of the party. In general, scholars identified two main paths to party unity: cohesion (homogeneity of political preferences) and discipline (sanctions provided). Both elements are crucial and are taken into account to explain the electoral behavior of the representatives (Bowler et al., 1999; Hazan, 2003) referenced in (CERON, 2015).

Regarding the first path (cohesion), the relationship between party affiliation and divergent political preferences has been investigated in recent studies. In another case study related to party affiliation in the Italian Left Democrats (DS), Giannetti and Laver (2009) cited by Ceron (2015), highlight how divergent generational preferences alter the degree of party unity and explain the variation in the electoral behavior of deputies. Ceron (2015), presenting Spirling and Quinn (2010), demonstrating that factional preferences can be linking within the party presenting a polarization as electoral behavior.

On the other hand, Ceron (2015), highlight that, when discipline is not effective, intraparty heterogeneity gives rise to heterogeneous electoral behavior, exerting a decline in the party agenda. On the contrary, when leadership can rely on effective resources of discipline, it will be able to impose, and the behavior of members will show homogeneity and adherence to the party agenda. Thus, polarization no longer has significant effects on party unity

\section{METHODOLOGICAL PATHS OF RESEARCH}

For the implementation of this work, a large bibliographic research was carried out, which resulted in extremely important analysis material, considering the aborted theme. The 
proposal is to verify in the literature the debate regarding the behavior of the parlamenta voter and present the ideologies as a function of influence of the behavior of the actions of the representatives of the legislature. Contemplating at the end of the work, the proposed questions regarding the definition and attributes that cover the profile and practices of members of parliament, as well as the institutional mechanisms that enabled the existence and reproduction of this group.

\section{THEORETICAL FRAMEWORK}

According to Messenberg (2017), Norberto Bobbio is one of the main advocates of understanding left and right thinking. He presents in his article Right and Left: reasons and meanings of a political distinction (1995), proposing a variety of principles that - according to Bobbio - can be observed in left and right ideologies. It clarifies that the right and the left are homogeneous and/or coherent political blocs, understanding that the left has an agenda oriented towards equality between men and the modification of the social order, while the right considers inequality as something inherent to humanity and maintaining the conservation of the corporate order. Observing these principles in industrialized countries and maintaining recurring ideas.

Thus, the left, excels in the egalitarianism of free trade, rationalism, secularism, criticism of ethical-religious limitations, the lack of absolute opinions of good and evil, the lack of appreciation to oligarchy, the conservation of the environment and the demands of workers, who must overlap the need for economic growth, antifascism and identity with the lower classes of society.

The right - according to Bobbio (1994) cited by Messenberg (2017), works with other ideals that include: individualism, the hegemony of private property and free enterprise, intuition, the precedence of the sacred, the recognition of order and tradition, nobility and heroism, inflexibility to ethnic, cultural and sexual difference, militarism and national security, economic growth at the loss of environmental conservation and the demands of workers, anti-communism and identities with the upper classes of society (MESSENBERG, 2017).

Thus, in the political field, the worldviews[2] of the left and right compose and extend 
"metapolitical field of daily social relations and cultural struggle" (Pierucci, 1990, p. 11) cited by (MESSENBERG, 2017). Being, allusion models from which individuals understand and relate to the world, constituting significance to their experience and clarifying the "order of things".

According to Messenberg (2017), currently the mass media and digital networks establish unique environments for the constitution of frameworks[3], organizing and selecting political positions. Such frameworks are consequences of a two-way process between the emitters and the receivers of knowledge, involving the repetition of interpretive and comprehensive patterns in a selective and manipulative way, involving values and symbols of common understanding, which are effectively backfed and/or reformed.

In addition to the media and party ideologies, the sociocultural, economic and ideological dimension of doing and thinking politics can be represented by the profile of parliamentarians. Identify the actors and their political practices, and understand how different sociocultural nuances intervene in the process of building and consolidating their careers and identities as politicians (MESSENBERG, 2007).

Bajoit (2006, p. 235) clarifies that each individual is continually in (re)constitution, assuming identity commitments: "he has a certain idea of what he is and what he wanted to be and what he believes he should do for it". In this sense, we must enter into social relations, participating in exchanges, exchanges and social connections. Therefore, each subject constructs logics of action with others, imbued with obtaining his personal identity. This process contributes to the construction of the social actor, being committed to the logics of action established by him in the relationship with the other.s. In order for the individual to resolve his conflicts of his life, in order to minimize or solve them, "he strives to reduce or increase the value he attributes to certain traits of his desired identities, attributed and compromised, in order to better reconcile them" (BAJOIT, 2006, p. 235). This process is called relational management of you.

The relational management of one's is also the work through which the individual "conceives" the logics of action. Commitment is the translation of compromised identity into logics of action over others. Taking into account the "idea" he has of what he is and wants to be, and the possibilities that open to him or close his ties 
with others in the different relational fields, the individual constantly rebuilds his "projects" of life (BAJOIT, 2006, p. 236).

Each individual, therefore, acts before others to carry out their commitments to themselves, through three ways: "always be with them in exchange relationships; participates, sometimes, in forms of collective solidarity; and may sometimes commit to collective actions" (BAJOIT, 2006, p. 236).

In reference to exchange relationships, in the following table there is the systematization of the exchange logics established by social actors to achieve their objectives, purposes, identities, etc., based on two criteria that allow to distinguish, define and classify their forms, as demonstrated in the table below:

Table 01: Exchange Logics.

\begin{tabular}{|c|c|c|c|c|c|}
\hline \multirow{9}{*}{ 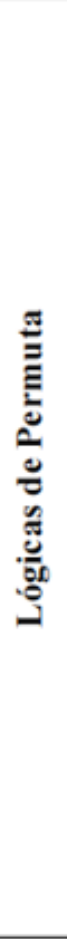 } & Critérios & Tipos & Permuta & Ação & Conceito \\
\hline & \multirow[t]{4}{*}{$\begin{array}{l}\text { Finalidades } \\
\text { da Permuta }\end{array}$} & \multirow[t]{2}{*}{ Inclusiva } & Complementar & Cooperar & $\begin{array}{l}\text { Cada ator só pode atingir sua finalidade } \\
\text { com a cooperação do outro. }\end{array}$ \\
\hline & & & Conflitual & Combater & $\begin{array}{l}\text { Deteriorização da cooperação. Cada parte } \\
\text { do conflito tem interesse em restabelecer } \\
\text { a cooperação. }\end{array}$ \\
\hline & & \multirow[t]{2}{*}{ Exclusiva } & Competitiva & Competir & $\begin{array}{l}\text { Um ator não pode atingir a sua finalidade } \\
\text { a não ser que impeça o outro de atingir a } \\
\text { sua. }\end{array}$ \\
\hline & & & Contraditória & Romper & $\begin{array}{l}\text { Cada ator tem interesse em suprimir o } \\
\text { outro, ou pelo menos, a relação com ele. }\end{array}$ \\
\hline & \multirow[t]{4}{*}{$\begin{array}{l}\text { A Estratégia } \\
\text { Relacional }\end{array}$} & \multirow[t]{2}{*}{ Consensuais } & Complementar & Cooperar & $\begin{array}{l}\text { Cada ator cumpre o seu papel para atingir } \\
\text { os objetivos coletivos e pessoais. }\end{array}$ \\
\hline & & & Competitiva & Competir & $\begin{array}{l}\text { Cada ator procura melhorar sua atuação } \\
\text { para estar à frente do outro, sem infringir } \\
\text { as regras. }\end{array}$ \\
\hline & & \multirow[t]{2}{*}{ Dimensionais } & Conflitual & Tumultuar & $\begin{array}{l}\text { Os atores deixam de estar de acordo e } \\
\text { põem em questão as condições da } \\
\text { cooperação. }\end{array}$ \\
\hline & & & Contraditória & $\begin{array}{l}\text { Destruir, } \\
\text { fugir }\end{array}$ & $\begin{array}{l}\text { Os atores não respeitam mais a relação, } \\
\text { destruindo ou fugindo dela. }\end{array}$ \\
\hline
\end{tabular}

Source: Bajoit (2006)

Considering the above table, it is infers that social actors organize different exchange logics to realize their personal identities, with different purposes and strategies. Therefore, each 
criterion produces types of exchange logics that will promote the strengthening or not of the relationship between the actors.

Corroborating the interpretation of the picture, Bajoit (2006, p. 241) summarizes:

We can also verify that each of these four logics can be coated in an amplified and latent way. Cooperation can be active or passive, conflict can be opened or disguised, the contradiction can be a direct confrontation or an escape, and competition can be offensive or reduce to a simple opportunism. The more the logics are latent, the better they combine with each other and coexist; the more they are amplified, the more they are mutually excluded.

Another way for individuals to relate and make their commitments to others is based on the logics of solidarity. According to Bajoit (2006, p. 242), "individuals who choose the logic(s) of exchange often (but not always) tend to recognize each other in action, and to build bonds of solidarity with each other." Recognition for the construction of relationships between individuals often involves the issue of commitment, because in order to realize their identity commitments, they need one another and thus sympathize.

The logics of solidarity are divided into two, where one is based on reciprocity and the other on Greekity, according to the table below:

Table 02: Logics of Solidarity.

\begin{tabular}{|l|l|l|}
\hline Lógicas de solidariedade & Lógica de reciprocidade & Lógica de gregariedade \\
\hline Lógica expressiva & Solidariedade afetiva & Solidariedade fusional \\
\hline Lógica instrumental & Solidariedade contratual & Solidariedade serial \\
\hline
\end{tabular}

Source: Bajoit (2006)

The author (idem) develops his theory by arguing that, in the logic of reciprocity, solidarity is a relationship based on "gift - against gift", because there is always "something" that is 
useful for someone and that someone is willing to exchange for something else, or for more of the same thing they need. Solidarity merges, builds and deconstructs, according to the commitment made and the need to maintain the relationship. The "things" may have different foundations, some of which are established in affection, in the exchange of moral or affective help, understood as expressive (advice, support, love, affection, respect, etc.). and others based on material or instrumental aspects (material resources, skills, work, information, money, etc.).

In affective solidarity, exchange is much more subjective, and individuals make their relationships of commitment in an expressive way; and receive it in return for the realization of their personal identity. When exchanges are material or instrumental, individuals perform contractual solidarity, which obeys an objective and much less subjective relationship.

According to Bajoit (2006), in the logic of aggregation, the relations of exchange and realization of commitments are more connected to the dynamics of groups, and, in groups, individuals can have something that is missing from all separately, but that when they then together, they have it.

In this understanding, things can also be divided into two aspects: one focused on things of subjective character and quality (religion, cause, social movement, struggle, courage to undertake, etc.). and those whose things are objective (strength, security, anonymity, etc.). When the things that are in return, in relation, are of subjective quality, we have the expressive logic, whose interest is in the need to develop them through groups, merging the personal identity with that of others, which together provide qualities that would not be if they were alone, generating the so-called fusional solidarity. On the other hand, when a personal identity becomes strength and security in addition to those of others, creating a strong group, it is called serial solidarity. In the meantime, these four logics of solidarity express the need to articulate with others in the realization of their personal identities, which, alone, would not be able to take effect.

Bajoit (2006, p. 243-244) stresses that social groups (family, church, working groups, trade unions, etc.) "they are all the more solid the more they can articulate all the logics: their members are then connected to each other by all ties at the same time." It is worth mentioning that the logics of solidarity start from the focus on the realization of individual 
commitments and personal identities, being independent of collective identities. However, Bajoit (2006, p. 244) points out that:

Of course, one of the indispensable conditions for the formation of solidarity is the socialization of individuals: that they occupy the same position in the relationship, who participate in the same collective identity. However, it is not a necessary condition: solidarity can be formed among individuals who do not occupy the same social positions (this is the case of altruistics, for example), as may also not form between individuals who occupy the same social position (different subject and exchange logics are adopted). Therefore, solidarity is not only anything more than identity, but also anything different. More generally, it depends on a complex set of conditions.

According to the citation above, the complex set of conditions necessary for solidarity to occur is what Bajoit calls collective action, formed by conditions that stimulate the social mobilization of the individuals involved and others who take collective action.

These conditions are classified as three components of collective action: the formation of organized solidarity; the composition of an opponent or enemy; and the elucidation of the objectives of the action. According to Bajoit (2006, p. 248), the presence of individuals engaged in any of these components is not enough for collective action to be fertilized. This, yes, allows the establishment of solidarity, however, the lasting social mobilization, aiming at achieving the desired results will depend directly on an organization made up of leaders, resources and traditions:

- Quality leadership: united, consistent, persevering, independent, competent, visible, combative, organized, charismatic;

- Resources for mobilization: money, relationships, information, weapons (real or symbolic);

- Traditions of struggles inscribed in a common history, with successes and failures to which the group can refer to guide their struggle today.

It is perceived that leadership is an extremely important factor for the effectiveness of collective action, whatever its objective or purpose. In this sense, understanding the leaders in solidarity economic enterprises is significant for understanding which logics of solidarity and exchanges individuals establish in self-management groups, as well as whether there are 
leaders who mobilize collective action of these groups in favor of the objectives they establish as structuring their personal identities.

The collective actor, by mobilizing, transforms the conditions of his existence, participating in the (re)construction of his own conditions. Therefore, social mobilization has its own dynamic, triggering certain processes:

Table 03: Social Mobilization Processes

\begin{tabular}{|l|l|}
\hline Processo de Explicitação & $\begin{array}{l}\text { A mobilização obriga geralmente os atores a explicitar, clarificar, a tornar } \\
\text { visiveis os componentes da sua ação e a interpelar outros atores da cena } \\
\text { social, elaborando a sua ideologia, legitimando e aumentando os laços de } \\
\text { solidariedade interna no grupo. }\end{array}$ \\
\hline Processo de Complexificação & $\begin{array}{l}\text { Os objetivos, frequentemente, são simples no início, mas o movimento fará } \\
\text { surgir outros, desencadeando conflitos e aumentando a complexidade do } \\
\text { processo. }\end{array}$ \\
\hline Processo de Escalada & $\begin{array}{l}\text { Uma vez que os atores entram nas permutas, são frequentemente incitados a } \\
\text { nelas permanecerem, e até a comprometerem-se nelas cada vez mais. }\end{array}$ \\
\hline Processo de Avaliação & $\begin{array}{l}\text { Ao conhecerem-se melhor, os atores aprendem a prever as condutas do outro, } \\
\text { a organizar-se e a estabilizar a sua liderança, favorecendo a comunicação e, } \\
\text { por conseguinte, aprendem a respeitar-se, a compreender-se e a preparar a } \\
\text { institucionalização do conflito. }\end{array}$ \\
\hline
\end{tabular}

Source:Bajoit (2006, p. 250-251)

Explaining the table above, it is perceived that social actors begin their logics of exchange, solidarity and even collective action based on processes that go, from the beginning, moving to deeper processes generated by the conflicts that arise with the engagement of the actors, and the actor explains why to establish the relationship with the group. With this, its relationship with collective action becomes stronger and the level of commitment and responsibility that the other members demand of this actor is increasing, resulting in processes of evaluation of the actions performed within the group, analyzing their performance.

According to Messenberg (2007), these characteristics of Parliament are not a natural phenomenon and are the result of the Legislative Power of making and imposing decisions on the members of the institution. The appointment of some parliamentarians for the occupation of privileged and strategic positions in the structure of the organization, thus representing a parliamentary elite. This parliamentary elite is characterized in the occupation of key 
positions of the Legislative Power, in the organized social and/or institutional interests and the recognition of peers of leadership as an individual characteristic. Therefore, it is these parliamentarians who exert influence on the main decisions in the Legislature, Executive and society. And their influences may contain cultural dimensions: economic and social interests of individuals and groups; national, sexual, social, religious and partisan identities. Therefore, Messenberg (2008), highlights that political culture is related to the democratization process, influencing the actors in the decisions of the Legislative Branch.

Relationships generate collective identities from which the people involved build their personal identities and engage in logics of action with, on, against, among others; and through which they reproduce or alternate the cultural senses (BAJOIT, 2006). On the other hand, Cavalcante (2012) understands that political, cultural and institutional differences do not explain or explain in parts, the variations in public policies not denying the influence of socioeconomic factors on the political dynamics and the results of public policies. It understands that the agendas of education, health and social assistance are less susceptible to the effects of politics, as housing and sanitation tend to suffer from the influence of these factors.

Bernabel (2015) works on the influences that can trigger political polarization. The concept of polarization and understood when members of a given party vote in one way and those of another party vote differently, these two parties can be described as polarized. There may be several causes to explain polarization. Bernabel (2015) snapping authors McCarty, Poole and Rosenthal (2006), where they argue that income, immigration and campaign finance can generate polarization. It also adds that the form (proportional or majority vote) as a legislator is elected can also have an effect on polarization. Parliamentarians elected by the majority rule tend to behave more extremely than those elected by the proportional rule, who vote more with their party. Paiva (2016), presents the analysis of public policies as a process that involves negotiations, conflicts and disputes of the public policy agenda, not ruling out the power to influence the decisions of the legislative power.

Bajoit (2006) understands that coexistence in collectivity, in society, in groups, implies the solution of some important issues, difficulties that, if not solved, can endanger individual existence. Thus, we can understand that parliamentarians seek to resolve conflicts aiming at their survival in ideological, personal or partisan debates. 


\section{CONSIDERATIONS}

The French philosopher Jean-Jacques Rousseau was one of the first heavyweights of hegemonic political culture. He intended to develop a political model that would ensure democracy, as private property promotes inequality and endangers freedom. A political model that established a state, upheld private property, and determined public property as something of everyone without belonging to any person. In this way, political representation would be at the service of all, however, being of all, it would not belong to anyone.

The parties act as actors, thus, the members exhibit the behavior according to their legend. However, this statement does not reflect reality. The parties are not structures of political monopoly, as they are usually composed of a variety of subgroups (i.e. factions) maintaining similar but not identical preferences.

Norberto Bobbio is one of the main advocates of understanding left and right thinking.

They draw attention to the heterogeneity of political preferences, the degree of partisanship, the impact of contrasting electoral rules or modes of party organization, the differences between government and opposition, the margin of the ruling coalition and the size of the party. In general, scholars identified two main paths to party unity: cohesion (homogeneity of political preferences) and discipline (sanctions provided).

In addition to the media and party ideologies, the sociocultural, economic and ideological dimension of doing and thinking politics can be represented by the profile of parliamentarians.

Individuals are continually in (re)constitution, assuming identity commitments: "you have a certain idea of what you are and what you want to be and what you believe you should do for it". In this sense, we must enter into social relations, participating in exchanges, exchanges and social connections.

The influences that can trigger political polarization. The concept of polarization and understood when members of a given party vote in one way and those of another party vote differently, these two parties can be described as polarized. 
We understand that this study does not include all the diversities that produce, divergences in the decisions of the votes of parliamentarians, requiring, for another moment, empirical samples, of the relationships and behavior of those indicated by society. Therefore, there is a gap for other studies or studies that investigate scans with data and quantitatively demonstrates true preferences or ideologies.

\section{BIBLIOGRAPHY}

ALDÉ, Alessandra. A construção da política: democracia, cidadania e meios de comunicação de massa. Rio de Janeiro: Editora FGV, 2004.

BAJOIT, Guy. Tudo muda: proposta teórica e análise de mudança sociocultural nas sociedades ocidentais contemporâneas. ljuí: Ed. ljuí, 2006.

BERNABEL, Rodolpho. A regra eleitoral é importante para a polarização política? O Caso das Câmaras Legislativas Brasileiras. Bras. Political Sci. Rev. vol.9 no.2 São Paulo mai / ago. 2015. https://doi.org/10.1590/1981-38212014000200012.

BENJAMIN, Cássio Corrêa. Schmitt e o problema da democracia. Nostalgia da transcendência ou a representação como questão para a democracia. Kriterion vol.49 no.118 Belo Horizonte Dec. 2008. https://doi.org/10.1590/S0100-512X2008000200008

BOBBIO, Norberto. Direita e esquerda: razões e significados de uma distinção política. São Paulo: Editora Unesp, 1994.

CAVALCANTE, P.L. C. A Política faz a diferença? Uma análise comparada dos determinantes políticos do desempenho dos governos municipais no Brasil. Tese apresentada como requisito parcial para a obtenção do Título de Doutor em Ciência Política pelo Programa de Pós-Graduação em Ciência Política da Universidade de Brasília. 2012.

CAVALCANTE, Pedro. A Implementação Municipal das Políticas Sociais: Uma Análise Espacial. Planejamento e políticas públicas | ppp | n. 42 | jan./jun. 2014.

CERON, Andrea. Brave rebels stay home: Assessing the effect of intra-party ideological 
heterogeneity and party whip on roll-call votes. Party Politics 2015, Vol. 21(2) 246-258, The Author(s) 2013 Reprints and permission: DOI: 10.1177/1354068812472581

ENTMAN, Robert M. Democracy without citizens: media and the decay or american politics. New York: Oxford University Press, 1989

GOFFMAN, Erving. Os quadros da experiência social: uma perspectiva de análise. Petrópolis: Vozes. 2012.

MCCARTY, Nolan; POOLE, Keith and ROSENTHAL, Howard. Polarized America: The Dance of Ideology and Unequal Riches. MIT Press, Cambridge, MA. 240p. 2006.

MESSENBERG, Débora. A Elite Parlamentar Brasileira: Um Recorte Sociocultural. Rev. Sociol. Polít., Curitiba, v. 16, n. 30, p. 17-28, jun. 2008.

MESSENBERG, Débora. A elite parlamentar brasileira (1989-2004). Sociedade e Estado, Brasília, v. 22, n. 2, p. 309-370, maio/ago. 2007.

MESSENBERG, Débora. O "alto" e o "baixo clero" do Parlamento brasileiro. Cadernos Aslegis, Brasília, v. 40, p. 79-107, mai./ago. 2010.

MESSENBERG, Débora. A direita que saiu do armário: a cosmovisão dos formadores de opinião dos manifestantes de direita brasileiros. Revista Sociedade e Estado - Volume 32, Número 3, Setembro/Dezembro 2017.

PAIVA, Ariane Rego de. Análise e avaliação de políticas sociais: algumas perspectivas do debate atual. O Social em Questão - Ano XIX - no 36 - 2016

PIERUCCl, Antônio Flávio. Ciladas da diferença. Tempo Social, v. 2, n. 2, p. 7-37, 1990

PINTO, J. R. S; GUIMARÃES, D. M.; BARROS, F. L. A Crise da Democracia Representativa. Elegis, Brasília, n. 19, p. 39-48, jan./abr. 2016, ISSN 2175.0688

WEBER, Max. A objetividade do conhecimento na ciência social e na ciência política. Metodologia das ciências sociais, v. 1. São Paulo: Editora Unicamp, 1992. 


\section{APPENDIX - FOOTNOTE REFERENCES}

2. The notion of worldview (Weltanschauung) adopted here is based on the Weberian sense (1992), which relates it to the cultural values or principles that underlie the conceptions of the universe and the philosophies of life of a society or group. Moreover, as Weber points out: “[...] worldviews can never be the result of an advance of empirical knowledge, and that, therefore, the supreme ideals that move us as hard as possible, exist, in every age, in the form of a struggle with other ideals that are, for other people, as sacred as they are to us others" (Weber, 1992: 113).

3. The notion of framing is taken here in the Goffmanian sense (Goffman, 2012) that is, as "cognitive structures, which organize thought, are composed of beliefs, attitudes, values and preferences, as well as rules on how to link different ideas. They are schemes that 'direct attention to relevant information, guide its interpretation and evaluation, provide inferences when information is flawed or ambiguous, and facilitate its retention'" (Fiske \& Kinder, cited by Entman, 1989, apud Aldé, 2004: 47).

${ }^{[1]}$ Master's degree in Economic Management of the Environment, Graduation in Economic Sciences.

Submitted: November, 2020.

Approved: December, 2020. 